University of Nebraska - Lincoln

DigitalCommons@University of Nebraska - Lincoln

Textile Society of America Symposium

Proceedings

Textile Society of America

2020

Modernist Influences in Churchill Weavers Textiles: 1922-1949

Sarah Stopenhagen Broomfield

Follow this and additional works at: https://digitalcommons.unl.edu/tsaconf

Digitalrt of the Art and Materials Conservation Commons, Art Practice Commons, Fashion Design

Cemmens, Fiber, Textile, and Weaving Arts Commons, Fine Arts Commons, and the Museum Studies

detwerkns

Logo

This Article is brought to you for free and open access by the Textile Society of America at

DigitalCommons@University of Nebraska - Lincoln. It has been accepted for inclusion in Textile Society of America

Symposium Proceedings by an authorized administrator of DigitalCommons@University of Nebraska - Lincoln. 


\title{
Modernist Influences in Churchill Weavers Textiles: 1922-1949
}

\author{
Sarah Stopenhagen Broomfield
}

\section{sarah.stopenhagen.broomfield@gmail.com}

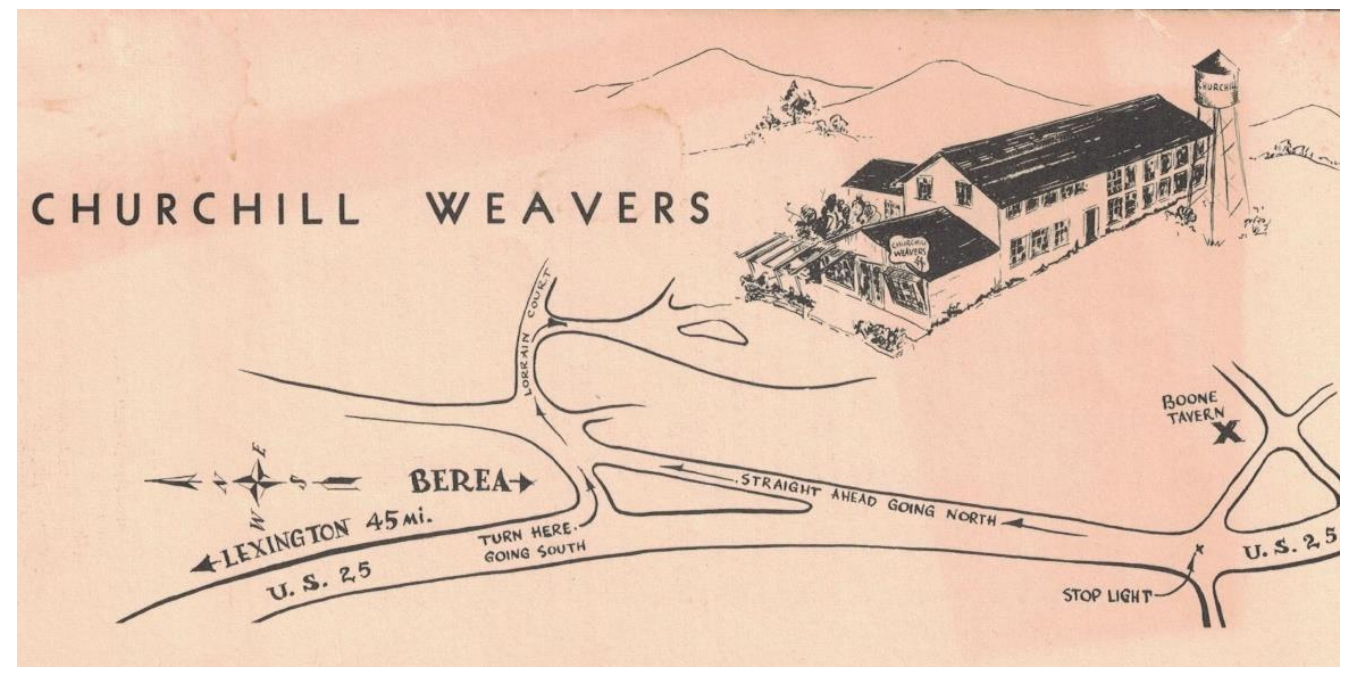

Figure 1.

Brochure circa 1930s from the author's collection of

Churchill Weavers ephemera

This research depicts part of the history of Churchill Weavers, a handweaving production center in Berea, Kentucky. The company was founded by the son of an Oberlin College professor, who was an Oberlin and MIT trained engineer; and the daughter of a Swedish immigrant, who was educated at Wellesley College. David Carroll Churchill (hereafter referred to as D. C. Churchill) worked in India for 16 years engineering improvements for the looms and equipment used by indigenous Indian handweavers. That work turned out to be foundational to the creation of the Churchill Weavers business with looms and equipment he designed and built on site in their Berea, Kentucky facility. D. C. Churchill met and married schoolteacher Eleanor Franzen (hereafter referred to as she called herself, Eleanor Churchill), in 1914, in India. For the last three of the six years that she lived in India she was immersed in his work among the handweaving sector.

In 1922, in Berea, Kentucky they founded Churchill Weavers which operated until closing in 2007. The Kentucky Historical Society is the home of the comprehensive collection of over 30,000 textiles and other artifacts from that company. I was fortunate to see what were called Master Samples in the basement of Churchill Weavers when I worked there as Designer in the decade of the 1980s; and seeing that collection eventually led me to this research. Modernist design influences in the fabrics of Churchill Weavers is an area that has not been investigated, but evidence suggests that hidden in craft production can be the germination of seeds sown by international design trends. This study focuses on three primary international influences in the early designs by founder and designer Eleanor Churchill for Churchill Weavers textiles. Her fusion of Indian, Swedish, and European Modernist trends brought an international look to an unlikely center of such cosmopolitanism in the place that settler colonialists call the Cumberland 
foothills of Appalachia. Eleanor Churchill was the first designer at Churchill Weavers and even after she started hiring designers so that she could focus on the management of the company, for as long as she was active in the company she had the final say in the designs that were to carry her name in the consumer world.

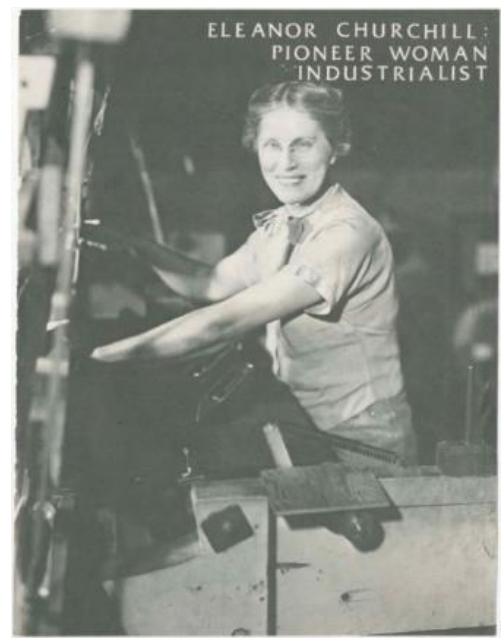

Figure 2.

Eleanor Churchill at a Churchill Weavers flyshuttle loom: Alumnae biographical files, 7B, Wellesley College Archives. Library and Technology Services, File: "Anna Eleanor Franzen Churchill."

During the years the Churchills lived in late-colonial India the influence of the British Arts and Crafts movement that promoted handweaving traditions for economic development, and the growing Swadeshi independence movement for Indian-made textiles would have influenced the fabrics they saw. The earliest Churchill Weavers textiles contain countless samples of sheer woolen stoles and scarves woven in 2/40 and 2/50 count worsted wools in bright tropical colors in designs reminiscent of Madras plaids (known as Pulicat in pre-colonial times).

The crossing of a warp of multi-colored stripes of varying widths by weft in varying width stripes and colors is an ancient weaving design that can be as simple as plain checks, or more varied in the size and number of the color stripes as seen in these samples. The stole below, woven in 1928, has color names evocative of the Asian world; colors like Indian Orange, Kashmir, Mosque, Sunray, Khiva, Ming, and Dark Kobe must have brought back memories of the years spent on the Indian continent.

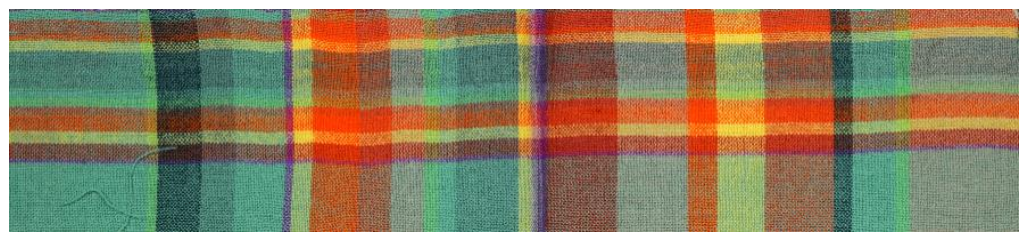

Figure 3.

"Kashan" Shawl in plain weave: Churchill Weavers Collection, Kentucky Historical Society 2007-45 Box 12-22 
Eleanor Churchill's granddaughter described her grandmother as having a photographic memory for not only text, but for color. ${ }^{1}$ She would have had a vast library cataloged in her mind from her six years of living in India. But she was a complex woman and there were other textile influences in her life which are important to explore.

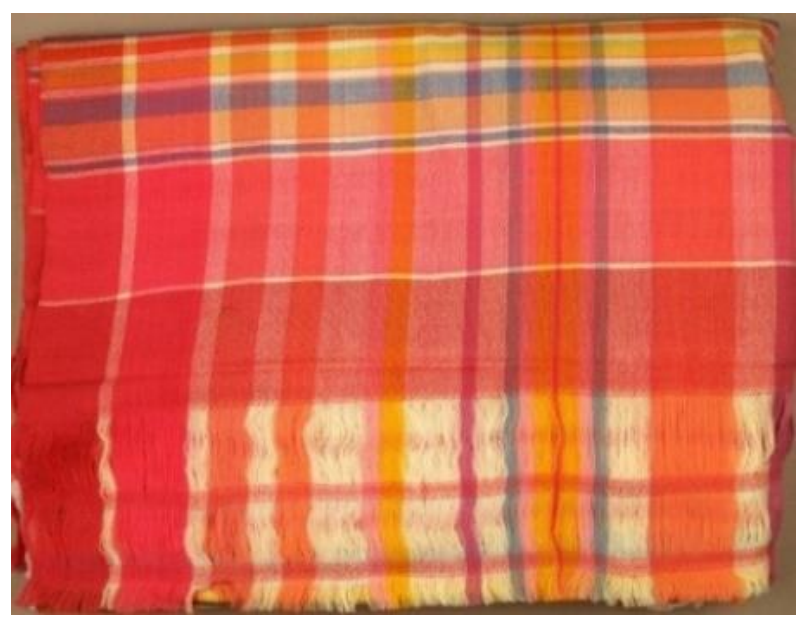

Figure 4.

"Kashan" shawl woven in the 1930s of 2/40 worsted wool: Churchill Weavers Collection, Kentucky Historical Society 2007-45 Box 31.22

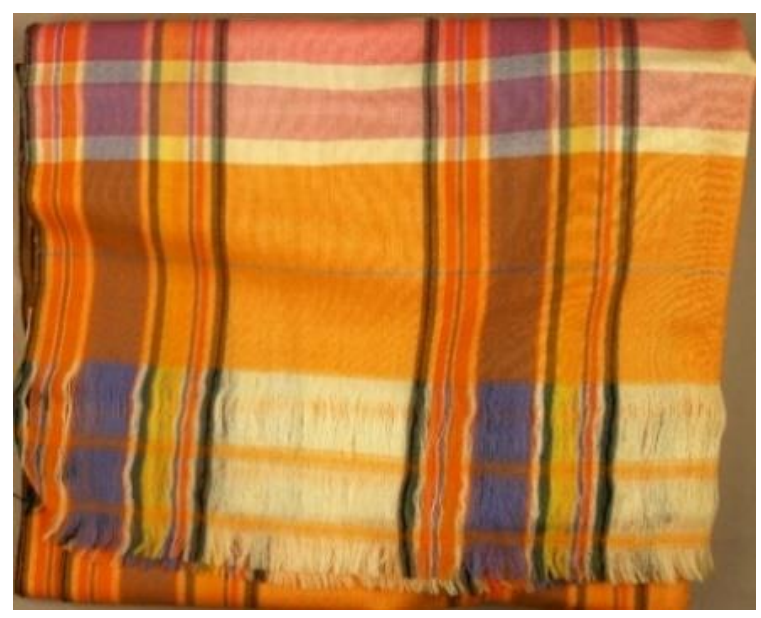

Figure 5.

"Kashan" shawl in plain weave 2/40 worsted wool, woven in 1930s: Churchill Weavers Collection, Kentucky Historical Society 2007-45 Box 31.24

Eleanor Churchill was likely exposed to a spectrum of Swedish textiles in the environment in which she grew up with a Swedish father who served and ministered to the Swedish immigrant communities of coastal Connecticut. In a marketing brochure she wrote in 1954, titled "Why Buy Handweaving?" she details the Danish, Swedish and Finish rooms in the UN building in New York as having draperies and upholstery woven by hand by expert handcrafters in their respective countries. In another passage from that same brochure she described the memories some held of seeing an elder in their family at a loom or cherishing an heirloom textile woven from family-raised sheep's wool. ${ }^{2}$ Clearly in her adulthood she had an appreciation for Swedish and other handwoven textiles and she drew on her memories of the handwoven textiles from her past.

Recent scholarship on historic texts discussing the strength of textile production and its importance in Swedish culture well before Swedish or Danish or Scandinavian Modern became an American consumer trend in the 1950s, are documented in the work Modern Swedish Design: Three Founding Texts. The writings of two Swedish thinkers from the turn of the century are analyzed by several scholars in that volume and they create a picture of the Swedish textile landscape in the first half of the $20^{\text {th }}$ century. Ellen Key was an early author who promoted the

1. Anne Cecil Noss, Interview by Sarah S. Broomfield, February 23, 2016. Interview Index, Interview of Anne Cecil Noss, Berea Community Life Oral History Project, Berea College Special Collections. Berea, Kentucky.

2. Eleanor Churchill, "Why Buy Handweaving?" 1954, Wellesley College Archives. Library and Technology Services, File: Alumnae biographical files, Eleanor Franzen, Collection 7B. 
look of clean Swedish interiors well before the 1930 Swedish Exhibition, which followed the 1925 Paris Exhibition of Designs for Modernity. Key, in her books Beauty for All (1889) and Beauty in the Home (1899), presented a concept of the importance of space and light in interiors, heavy furniture was replaced with simple and lightweight furniture; healthy eating habits, exercise, and fresh air were essential to human health and light was welcomed into the home. ${ }^{3}$ Key favored eliminating decorative design in favor of clean interiors, and for her, windows were an essential element of an interior that let nature in, and thus should be treated as such. "Why is light, airy drapery around a window more beautiful than a heavy and dark one? Because the latter is contrary to the principal of a window which is to let light in." "There are samples of light and airy drapery fabric from Churchill Weavers dated in the 1930s that exhibit those qualities.

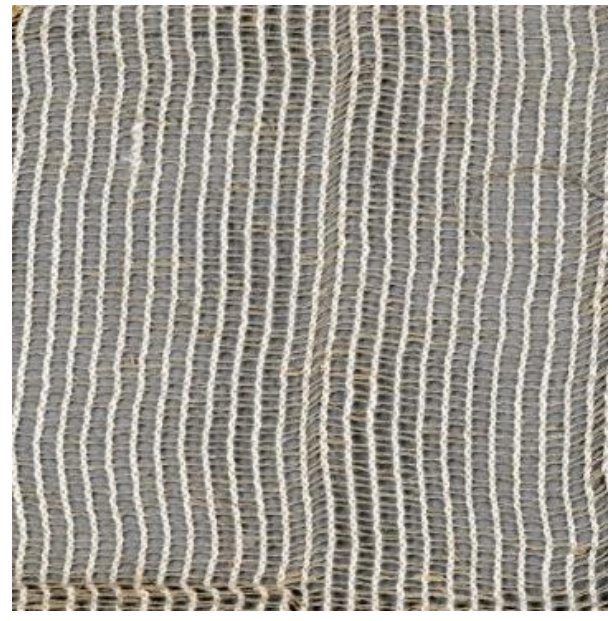

Figure 6.

Cotton-linen curtain fabric in leno weave, woven in 1936; Churchill Weavers Collection, Kentucky Historical Society 2007-45 Box 31.352

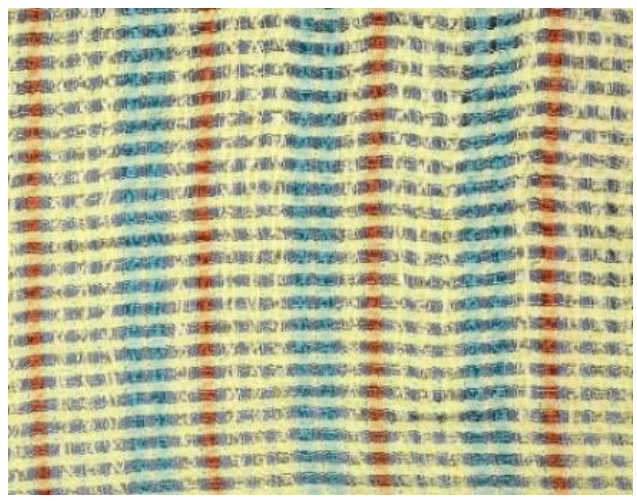

Figure 7.

Sheer cotton curtain fabric, woven in1930: Churchill Weavers Collection, Kentucky Historical Society 2007-45 Box 31.306-9

The other historic Swedish author discussed in Modern Swedish Design is Gregor Paulsson, who had a long career in crafts promotion through Swedish Arts and Crafts Societies and as the designer for the Swedish exhibit in the 1925 Paris Exhibition, in exhibits from that show that toured America cities from 1925-1930, and for the Stockholm Exhibition of 1930. Paulsson promoted the handcrafts and stated that "...traditional handwoven fabrics could function as a model for the evolving textile industry." Through his influence and others, Americans were able to see modern fabrics coming from Sweden in exhibits in major department stores, and in journal articles. Eleanor Churchill would have been paying attention to those trends in textile design.

3. Kenneth Frampton, "The Untimely Timeliness of Swedish Modernism," in Modern Swedish Design: Three Founding Texts, Uno Ahren, Gunnar Asplund, Wolter Gahn, Ellen Key, Sven Markelius, Gregor Paulsson, and Eskil Sundahl (New York: Museum of Art, 2008), 16.

4. Ellen Key, "Beauty in the Home," in Modern Swedish Design, 50

5. Kjetil Fallan, Scandinavian Design- Alternative Histories (London: Berg, 2012), 52. 


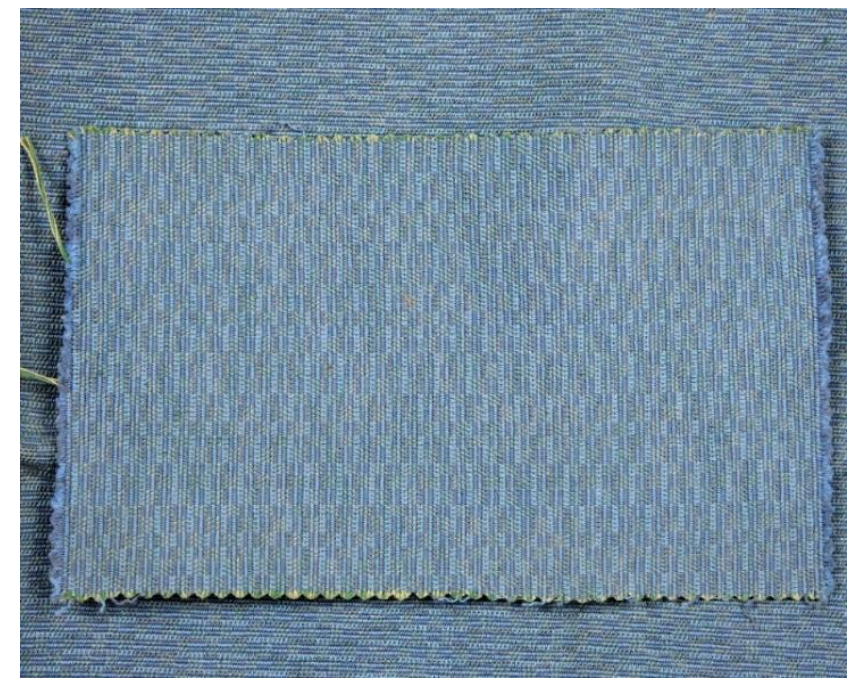

Figure 8.

Commissioned handwoven upholstery fabric for the Toledo Art Museum, 1932: Churchill Weavers Collection, Kentucky Historical Society 2007-45 box 31.2011

Analysis of a 1932 textile designed for the first commission work woven by Churchill Weavers shows converging influences. The commission order was for upholstery fabric for chairs in the Toledo Art Museum's Peristyle auditorium.

The upholstery fabric exhibits a sensitivity to color, texture, and to the purpose of the fabric. Here is how Eleanor Churchill described the process by which they arrived at the color for this commission. "We found that in order to get the right color effect we had to use the Impressionist method of color,-i.e. letting the eye and the mind combine the colors instead of mixing the color in the dye and then dyeing the yarn, so we finally came up with taking three individually dyed colors and using them in a special weave which would give us the effect which we were after." 6 Did Swedish textile design trends influence such a design? It is hard to tell, but this is not the kind of product being handwoven in any other production center in the Appalachian region in 1932. Many of those centers were still reproducing colonial overshot patterns and looking to the past, not the future. ${ }^{7}$

In the 1930s, photographing of textiles brought another new dimension to handwoven textile marketing, and to how textiles were presented to consumers. Innovations from the Bauhaus in textile photography will be addressed later, but Scandinavian countries already employed that trend by the 1930 s. Craft Guild.

6. Eleanor Churchill letter to Garry Barker, September 13, 1968, The Archives of the Southern Highland

7. According to the Archivist at the Toledo Museum of Art, that 88-year-old handwoven upholstery still covers the chairs in the Toledo Museum at the time of this writing, a testament to the timeless quality of that design produced by Churchill Weavers. Julie McMaster email to Sarah S. Broomfield 7/20/2019. 
Kjetil Fallen, in Scandinavian Design describes "new kinds of images in the form of carefully constructed photos portraying the structure and quality of woven textiles...heaps of cascading fabrics, close-ups of folded and twisted weaves showing the transparency of a curtain fabric and

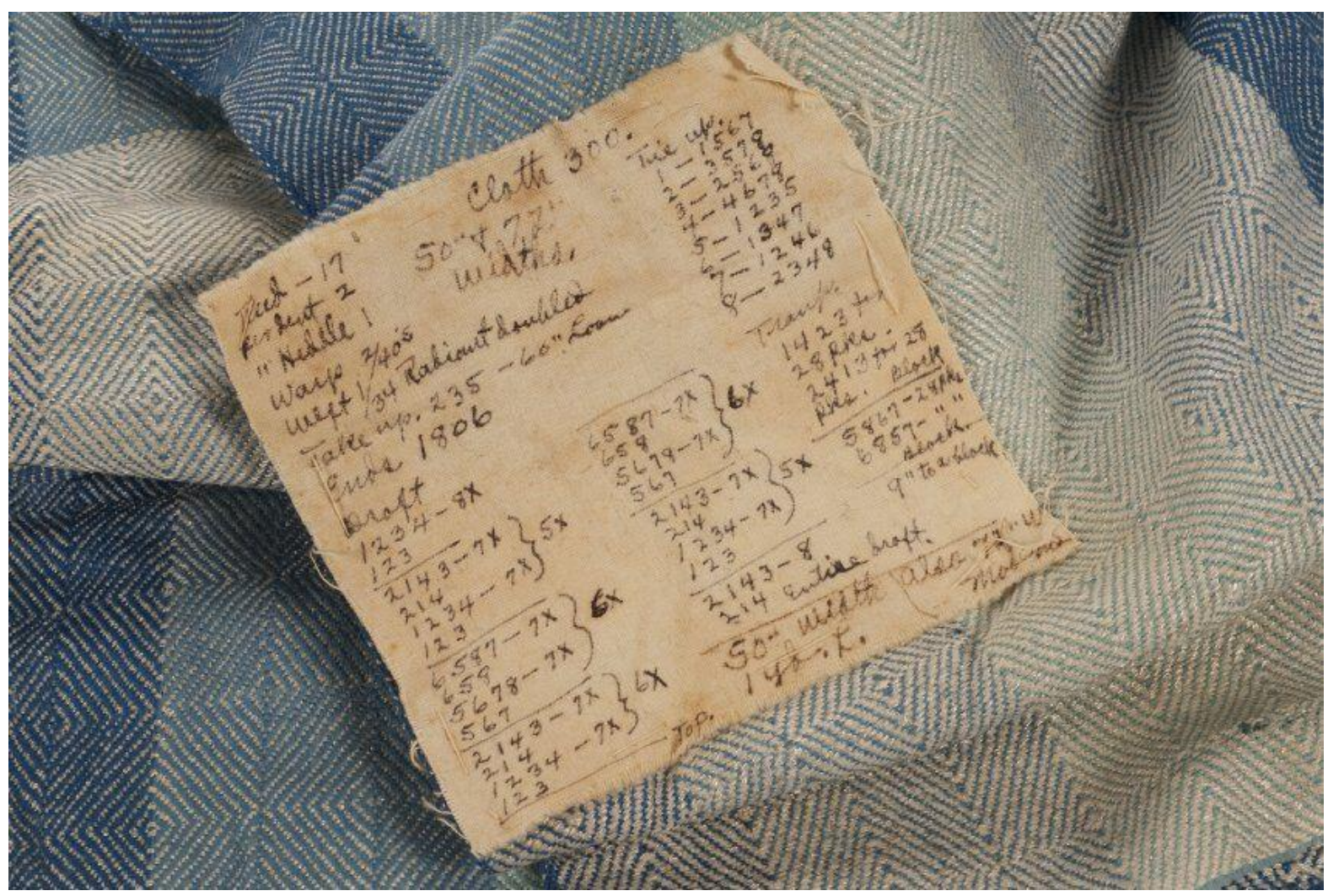

Figure 9.

Wool - silk yardage for upholstery or suiting, woven in1930: Churchill Weavers Collection, Kentucky Historical Society 2007-45 Box. 31.60

the gloss in the surface of a damask, or cropped takes of heavy carpets with rough pile and distinctive materials." ${ }^{8}$ Modern textiles (or functionalist- the term preferred by Nordic countries) were recognized by their emphasis on the weave structure, the qualities of the materials selected for the fabric, and the textures created by the hardness or softness of the yarn and their interlacement. Those textile qualities will be explored further with a synopsis of the innovations coming from the Bauhaus school, which opened in Germany in 1919 and was de-funded and closed in 1933 by the Nazis.

The structure, color effect, and technical properties of the cotton upholstery fabric designed by Eleanor Churchill for the Toledo Art Museum illustrates a design sense that paralleled one coming from other European sources in the early decades of the $20^{\text {th }}$ century. The influence of the Bauhaus Weaving Workshop cannot be overlooked as another potential influence on the designs Eleanor Churchill produced. While Churchill Weavers started with women's accessories

8. Fallan, Scandinavian Design, 49. 
and only occasionally produced upholstery fabric, those fashion accessories incorporated the use of mixed textures and color placement designed to build dimension into the fabrics.

Rayon/wool blend yarn with a subtle sheen added brightness to their custom-dyed yarn and was a basic in the production line for decades.

Newly manufactured textured yarns like rayon boucle built a layer of depth into their fabrics.

The women of the Bauhaus Weaving Workshop left a formidable legacy which is documented in T'ai Smith's text Bauhaus Weaving Theory: From Feminine Craft to Mode of Design.

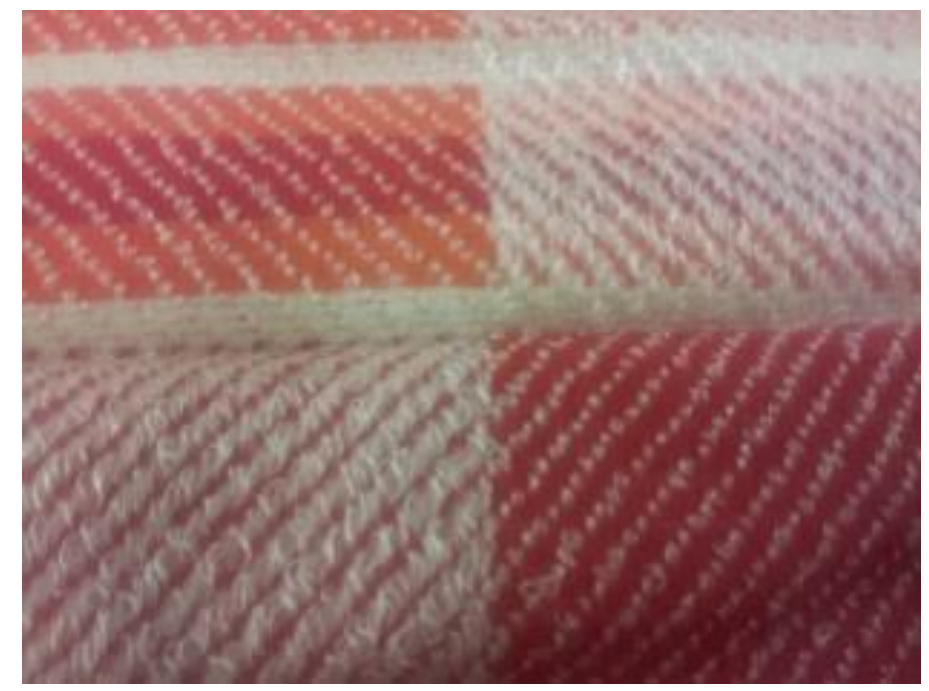

Figure 10.

Wool and rayon "Berylette" stole, 1942: Churchill Weavers Collection, Kentucky Historical Society 2007-45 box 31.575

Smith states: “...Bauhaus weavers began writing essays to develop parameters (and justifications) for their woven objects- unlike most of their craft-workshop colleagues at the Bauhaus, the weavers were avid about the practice of writing; they were preoccupied with formulating (and reformulating) their Craft..." From the rich legacy of the writings of the Bauhaus weavers, Eleanor Churchill must have followed their evolution of thinking about textiles and design, art, craft, and industry. Bauhaus weavers knew that to market their textile products the item had to be useful for something- for example, as curtain fabric, or blankets, and their clientele was largely female. Smith asserts that the texts of the Bauhaus women weavers were modernist in their focus on the distinct function of the textile, and states that their "...early weaving theory joined together the rhetoric of functionalism, modern marketing, and the new woman's movement." 10

Innovations in the use of newly manufactured synthetic yarns was another contribution of the Bauhaus Weaving Workshop. British handweaver and writer Ethel Mariet wrote a textbook on handweaving in 1939 that commented on those innovations from the Bauhaus. She described innovative uses of synthetic yarns that included cellophane, rayon, other new synthetics, and the use of bast fibers like jute.

We see Churchill Weavers using many of these same fibers in their weavings of that period. Clearly Eleanor Churchill embraced the new fibers in her designs from her Kentucky-based

9. T'ai Smith, Bauhaus Weaving Theory: from Feminine Craft to Mode of Design (Minneapolis: University of Minnesota Press, 2014), xiv.

10. Smith, Bauhaus Weaving Theory, 44. 
handweaving center and she continued to explore designing with mixed fibers — shiny and dull, natural, and synthetic.

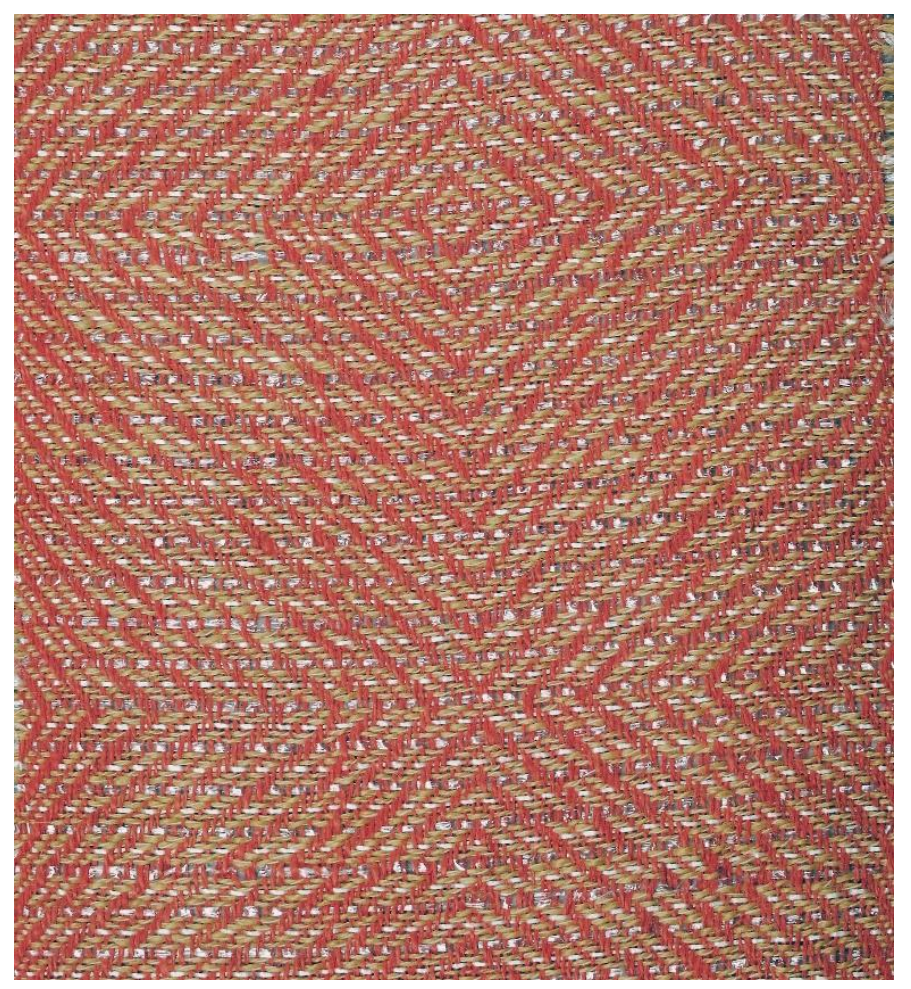

Figure 11.

Placemat woven on jute warp with cellophane weft, 1938: Churchill Weavers Collection, Kentucky Historical Society 2007-45 box 31.2255

The placemat above from 1938, was woven with a jute warp and a weft of cellophane; a mixture of a light-reflective yarn with a dull and light-absorbing fiber, constructed in a multi-harness twill weave. The structural emphasis on the bold geometric twill pattern is accentuated using the new shiny yarn paired with the natural jute fiber.

The fabrics of the Bauhaus Weaving Workshop were documented in print journals and in international exhibitions, they offered inspiration to handweavers the world over; but photographs of the Bauhaus textiles also inspired. Smith states: "Photography acted as a lens through which texture could (literally) be seen, and through which weaving at the Bauhaus came to be recognized." "For Eleanor Churchill, who majored in the study of the German language and culture as an undergraduate, it would have been difficult for her to ignore this direction in textile design. In addition to international stimulus for designs, there were regional and even local factors that brought the modernist look to Berea through the artists hired by Berea College 
to teach in their Art Department, and the European exiles who taught at the nearby Black Mountain College in North Carolina.

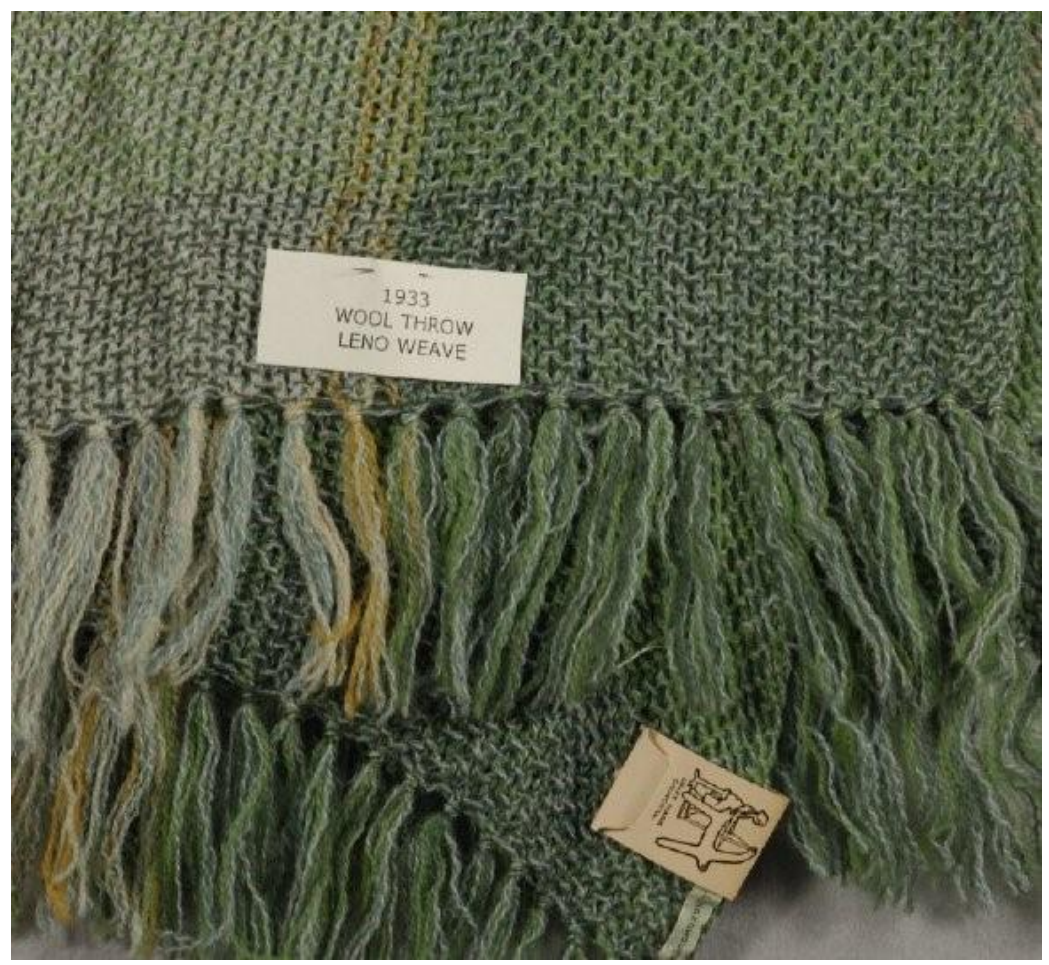

Figure 12.

Worsted wool yarns woven in a plaid design in a textured leno weave, 1933: Churchill Weavers Collection, Kentucky Historical Society 200745 Box 31.1488

Eleanor Churchill's personal life is not well documented in the collection of Churchill Weavers artifacts at the Kentucky Historical Society, but several oral history interviews helped build an image of the friendships she developed in the Berea College art community. One of those friendships was with Mary Ela, Art Department Chair at Berea College, who had an undergraduate degree from Oberlin College, and studied at the Art Institute of Chicago and in Paris. Ela was responsible for hiring faculty with backgrounds that included several with training under Bauhaus and Cranbrook teachers, bringing modernist ideas into the Art Department. The Churchills were especially fond of developing relationships with faculty members who shared their ties to Oberlin College, and one of those friendships was with a painting professor. In an oral history interview with Lester Pross, he mentioned "Eleanor (Churchill) showed me her Feininger works one time. I had no idea where they came from." ${ }^{12}$ In the 1938-39 academic year, (prior to Pross joining the faculty in 1946) the Berea College Art Department had an exhibit of

12. Lester Pross. Interview with Sarah S. Broomfield. July 18, 2015. Interview Index, Interview with Dr. Robert Boyce and Mr. Lester Pross, Berea Community Life Oral History Project, Berea College Special Collections, Berea, Ky. 
the "paintings, watercolors and drawings by Lyonel Feininger..."13 Perhaps some of those exhibited works were for sale and that is where Eleanor Churchill had purchased them, knowing she was buying original art by a former Bauhaus artist and teacher. In the 1939-1940 academic year the Berea College art department hosted a series of talks about teaching in the arts by Josef and Anni Albers, former Bauhaus teachers, both of whom were Black Mountain College faculty members. Cultural events brought to Berea to benefit the students would have captured the attention of Eleanor Churchill, and she would not have missed the opportunity to see works of modern art or to meet with visiting artists of international acclaim.

Josef and Anni Albers were no longer an ocean away at the Bauhaus, but only four hours away from Berea, Kentucky. The Berea College Art Department faculty took advantage of that proximity as they planned exhibits and invited guests to visit campus and give talks. Eleanor Churchill must have known about Feninger's 1939 visit and about the invitation to bring Josef and Anni Albers from Black Mountain College to meet with the Art Department faculty and present talks on campus in the spring term of 1940.

In the faculty files of Black Mountain College, there was one small piece of evidence of that knowledge. A typed letter written by Anni Albers from Mexico on June 15, 1939, to Anne Mangold, secretary at Black Mountain College, contained these opening sentences: "Thanks so much for your card. Could you keep the little package from the Churchill weavers for me, I don't need it here." 14 Who sent that package and what could it have contained? There was no record of any follow-up communication found to answer those questions, but someone from Churchill Weavers had sent something to Anni Albers in anticipation of her visit to Berea the following spring. Could it have been sent by Eleanor Churchill, was it some yarn samples, a handwoven item from their production line, or even an experimental piece exploring a new weave or yarn? There are no answers to these and other questions, despite checking with the archivist at the Josef and Anni Albers Foundation for leads. However, we do know that the next spring, Josef Albers gave his talk titled "The Meaning of Art" on March 12, 1940 at Berea College. ${ }^{15}$

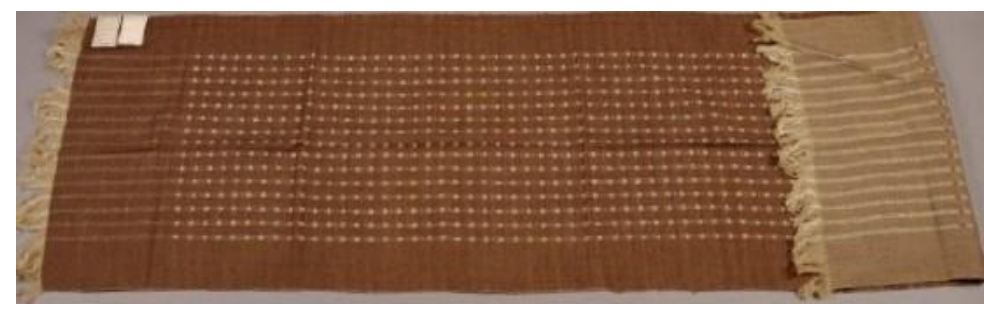

Figure 13.

The "Moderne" wool scarf in a reversable summer and winter weave, 1938: Churchill Weavers Collection, Kentucky Historical Society 2007-45

Box 31.424

13. Robert Boyce, History of the Berea College Art Department, One Man's Reading (Berea; Berea College Printing, 2008), 78.

14. Anni Albers letter to Anne Mangold, June 15, 1939, NC State Archives, Black Mountain College, III. Faculty Files, Folder 5, Albers, Josef, Mrs.

15. Josef Albers, "The Meaning of Art," lecture given at Berea College, Berea, Kentucky, March 12, 1940, The Josef and Anni Albers Foundation, Josef Albers papers, box 39, folder 26. 
Eleanor Churchill used some of the same terminology to market handwoven textiles that was utilized by those marketing handweaving in Sweden and by those who had immigrated from the Bauhaus School to teach in American art schools. Eleanor Churchill wrote of the artisan and handweaver creating designs that would eventually be produced by the power loom industry. She wrote to convince her customers that spending money on a handwoven item of "modern design" could allow "all the people of our country to have more beautiful cloth. Manufacturers watch trends in the sale of handwoven material, and when a new pattern or material shows great promise, they adapt it to the requirements of the machine-loom. The net result often is that attractive new weaves are made available to millions." 16

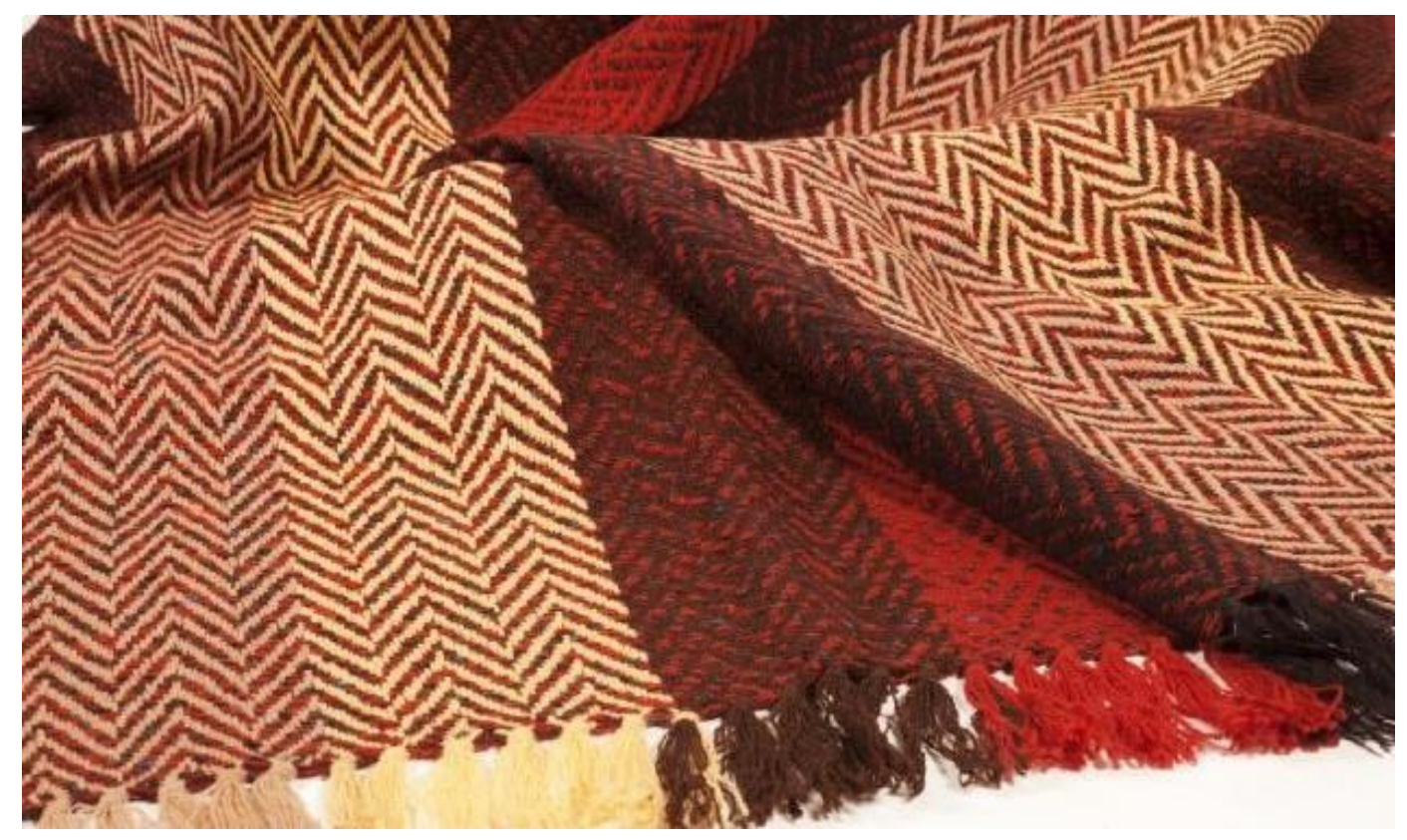

Figure 14.

Herringbone couch throw in 2/26 worsted wool, 1944: Churchill Weavers Collection, Kentucky Historical Society 2007-45 Box. 31.1498

Through a convergence of Indian, Swedish, and Bauhaus textile influences and the engineering, artistic, and business skills of D. C. Churchill and Eleanor Churchill, their story is one of a melding of traditional textile practices with modern design in their craft production center located in Kentucky's Appalachian foothills. As envisioned in India decades earlier, the artisanal craft of handweaving was preserved in the Churchill Weavers production center, while providing steady employment for rural workers who were predominately women. There, the craft was modernized, but in a way that maintained craft as distinct from modern industry. The distinctive handwoven products of Churchill Weavers became recognized and prized for superb quality of materials and technical production, elegant Modern design, and affordability for middle class consumers.

16. Eleanor Churchill, "Why Buy Handweaving?” 1954, Wellesley College Archives. Library and Technology Services, File: Alumnae biographical files, Eleanor Franzen, Collection $7 \mathrm{~B}$. 


\section{Bibliography}

Alvic, Phyllis. Weavers of the Southern Highlands. Lexington: The University Press of Kentucky, 2003.

Arnason, H. Harvard and Elizabeth Mansfield. History of Modern Art: Painting, Sculpture, Architecture, Photography. Boston: Pearson, 2013.

Aron, Jamie Suzanne. "Woven Images: From the Bauhaus Weaving Workshop to the Knoll Textile Division." UCLA Electronic Theses and Dissertations, July 9, 2017, http://escholarship.org/uc/item/6gp0d68k.

Auther, Elissa. String, Felt, Thread: The Hierarchy of Art and Craft in American Art. Minneapolis: University of Minnesota Press, 2010.

Baker, Henry. British India: With Notes on Ceylon, Afghanistan and Tibet. Washington: Government Printing Office, 1915.

Bauer, Catherine. Modern Housing. Cambridge: The Riverside Press, 1934.

Baumhoff, Anja. The Gendered World of the Bauhaus: The Politics of Power at the Weimar Republic's Premiere Art Institute. Frankfurt am Main: Peter Lang Publishing, 2001.

Benfey, Christopher. Red Brick, Black Mountain, White Clay. New York: The Penguin Press, 2012.

Boyce, Robert. History of the Berea College Art Department, One Man's Reading. Berea: Berea College Press, 2008.

Boyce, Robert. Interview by Sarah S. Broomfield. July 18, 2015. Interview Index, Interview with Dr. Robert Boyce and Mr. Lester Pross, Berea Community Life Oral History Project, Berea College Special Collections. Berea, KY.

Chamberlain, Ernest Barrett. The Churchills of Oberlin. Oberlin: Oberlin Improvement \& Development Organization, 1965.

Chatterjee, Atul Chandra. Notes on Industries of United Provinces. Madras: The Minerva Press, 1907.

Churchill, David Carroll. "The Handloom in Ahmednagar," The Report on the Third Indian 
Industrial Conference. Madras: The Minerva Press, 1907, accessed January 21, 2018, https://archive.org/stream/in.ernet.dli.2015.224555/2015.224555.Report-Of_djvu.txt.

Churchill, David Carroll. Letters in American Board of Commissioners for Foreign Missions Archives, 1810-1961 (ABC 1-91), Box 4 Mission Field Papers: Correspondence with Missionaries, 1877 - 1928, Letters from India, Marathi Mission: Folder 6. Churchill, Mrs. D. C. (Alice), 1910-1911. Houghton Library, Harvard University.

Churchill, David Carroll. Box 1 of 18, Log \#424, 7/8/1993, Churchill Weavers Correspondence, folder: David Carroll Churchill. Special Collections, Berea College Hutchins Library.

Creagh, Lucy, Helena Kaberg, and Barbara Miller Lane. Modern Swedish Design- Three Founding Texts. New York: The Museum of Modern Art, 2008.

Danilowitz, Brenda. Anni Albers Selected Writings on Design. Hanover: Wesleyan University Press, 2000.

Diaz, Eva. The Experimenters: Chance and Design at Black Mountain College. Chicago: University of Chicago Press, 2015.

Fallan, Kjetil editor. Scandinavian Design- Alternative Histories. London: Berg, 2012.

Green, Chris. The Social Life of Poetry: Appalachia, Race and Radical Modernism. New York: Palgrave/McMillan, 2009

Harris, Mary E. The Arts at Black Mountain College. Cambridge: The MIT Press, 1987.

Haynes, Douglas E. Small Town Capitalism in Western India: Artisans, Merchants, and the Making of the Informal Economy, 1870-1960. New York: Cambridge University press, 2012.

Hokanson, Suzanne Work. Woven: A Bauhaus Memoir. Troy: The Troy Bookmakers, 2006.

Houze, Rebecca. "Marketing Domesticity with Fashionable Interior Design.” Design Issues 18, no. 1 , Winter (2002).

Johnson, J. Stewart. American Modern 1825-1949- Design for a New Age. New York: Abrams, 2000.

Kardon, Janet. Craft in the Machine Age, 1920-1945. New York: Abrams, in association with the American Craft Museum, 1995.

Linnea, Martin. The History \& Development of the Bauhaus Weaving Workshop 1919-1939. 
University Park: Penn State University Press, 1976.

Mairet, Ethel M. Hand-Weaving to-Day. London: Faber and Faber, 1939.

McGowan, Abigail. Crafting the Nation in Colonial India. New York: Palgrave Macmillan, 2009.

Meta, Khan B. B. D., Alfred Chatterton, papers in The Report on the Third Indian Industrial

Conference, Madras: The Minerva Press, 1907, accessed January 21, 2018,

https://archive.org/stream/in.ernet.dli.2015.224555/2015.224555.Report-Of_djvu.txt.

Muller, Ulrike. Bauhaus Women: Art, Handicraft, Design. Paris: Flammarion S. A., 2009.

Noss, Anne Cecil. Interview by Sarah S. Broomfield. February 23, 2016. Interview Index, Interview of Anne Cecil Noss, Berea Community Life Oral History project, Berea College Special Collections. Berea, KY.

Pross, Lester. Interview by Sarah S. Broomfield. July 18, 2015. Interview Index, Interview of Dr. Robert Boyce and Mr. Lester Pross, Berea Community Life Oral History project, Berea College Special Collections. Berea, KY.

Report on the Administration of the Madras Presidency During the Year 1907-1908. Madras: Government Press, 1908. Accessed May 21, 2018. https://archive.org/stream/in.ernet.dli.2015.17295/2015.17295.Report-On-TheAdministration-Of-The-Madras-Presidency-During-The-Year-1907-08_djvu.txt

Rodgers, Daniel T. Atlantic Crossings: Social Politics in a Progressive Age. Cambridge: The Belknap Press of Harvard University Press, 1998.

Rowland, Anna. "Business Management at the Weimar Bauhaus." Journal of Design History 1, no. 3/4, 1988.

Rubin, Cynthia Elyce. “Bauhaus Textiles: A Legacy of Female Hands.” Fiberarts 36, no. 3, 2009.

Ryan, David. “Scandinavian Moderne: 1900-1960." Minneapolis: Minneapolis Institute of Arts Accessed March 6, 2016. http://archive.artsmia.org/modernism/e_SM.html.

Smith, T'ai. Bauhaus Weaving Theory: From Feminine Craft to Mode of Design. Minneapolis: University of Minnesota Press, 2014.

Troy, Virginia Gardner. The Modernist Textile: Europe and America, 1890-1940. Aldershot: Lund Humphries, 2006. 
Weltge, Sigrid Wortmann. Women's Work: Textile Art from the Bauhaus. San Francisco: Chronicle Books, 1993.

Willett, John. Art and Politics in the Weimar Period: The New Sobriety, 1917-1933. New York: Da Capo Press, 1978.

Wingler, Hans. The Bauhaus: Weimar, Dessau, Berlin, Chicago. Cambridge: The MIT Press, 1969. 